\title{
Two-stage in vitro digestibility assay, a tool for formulating non-starch polysaccharide degrading enzyme combinations for commonly used feed ingredients of poultry rations
}

\author{
J. Narasimha, D. Nagalakshmi, Y. Ramana Reddy and S. T. Viroji Rao \\ AICRP on Poultry Breeding, Department of Animal Nutrition, College of Veterinary Science, Rajendranagar, \\ Sri Venkateswara Veterinary University, Hyderabad, Andhra Pradesh - 500030, India \\ Corresponding author: Narasimha Jatoth, E-mail: simha_vet@yahoo.com \\ Received: 09-01-2013, Revised: 13-02-2013, Accepted: 14-02-2013, Published online: 24-05-2013
}

\begin{abstract}
How to cite this article: Narasimha J, Nagalakshmi D, Reddy YR and Rao STV (2013) Two-stage in vitro digestibility assay, a tool for formulating non-starch polysaccharide degrading enzyme combinations for commonly used feed ingredients of poultry rations, Vet World 6(8): 525-529, doi:10.5455/vetworld.2013.525-529
\end{abstract}

\begin{abstract}
Aim: An attempt was made to assess the effect of pure enzyme combinations with the objective of formulating customized enzyme mixtures based on sugar release when subjected to two-stage in vitro digestion assay.

Materials and Methods: A two-stage in vitro digestibility assay was carried out for commonly used feed ingredients for poultry viz., maize, soy bean meal, sunflower cake, and de-oiled rice bran supplemented with three concentrations of xylanase (5000; 7500 and $10000 \mathrm{IU} / \mathrm{kg})$, cellulase (50; 100 and $400 \mathrm{IU} / \mathrm{kg}$ ) and $\beta$-D-glucanase (100; 200 and $400 \mathrm{IU} / \mathrm{kg}$ ) were used to formulate various NSP enzymes combinations. In total 27 NSP enzyme combinations $(3 \times 3 \times 3)$ were formulated and the sugar released due to NSP digestion was quantified by phenol sulphuric acid method.

Results: The total sugar release was significantly $(P<0.05)$ higher with supplementation of various enzymes combinations for maize, sunflower cake and de-oiled rice bran where as no significant $(P<0.05)$ interaction of various NSP enzymes combinations was observed for soy bean meal. The NSP digestibility was highest in combination (xylanase-5000, cellulase-50 and $\beta$-D-glucanase-400 IU/kg), (xylanase-10000, cellulase-50 and $\beta$-D-glucanase-200 IU/kg) and (xylanase-7500, cellulase100 and $\beta$-D-glucanase-100 IU/kg) for maize, sunflower cake and de-oiled rice bran respectively. In case of sunflower cake, significant $(P<0.01)$ three way interaction was observed among the xylanase, cellulose, and $\beta$-D-glucanase enzymes and the two-way interactions between the enzymes were also significant $(P<0.01)$.

Conclusion: It is concluded that ' $n$ ' number of non-starch Polysaccharide enzymes combinations can be screened for their efficiency to digest non-starch Polysaccharides present in various feed ingredients commonly used in poultry rations by employing two-stage in vitro digestibility assay as a tool.
\end{abstract}

Key words: feed ingredients, in vitro digestibility assay, non-starch polysaccharide enzymes

\section{Introduction}

Polysaccharides are major components of plant materials used in rations for poultry. They are macromolecular polymers of monosaccharides linked by glycosidic bonds [1]. The Non-starch Polysaccharides are principally non $\alpha$ glucon polysaccharides of the plant cell wall. They are heterogenous group of polysaccharides with varying degree of water solubility, size and, structure [2]. Nonstarch polysaccharides (NSP) include celluloses, hemicelluloses, pectines, and oligosaccharides $(\alpha-$ galactosides, etc.). They can also be divided into watersoluble and water-insoluble fractions; fr which have greater relevance to their nutritional values. Birds do not possess endogenous enzymes capable of cleaving and digesting the $\beta(\alpha)$ linked NSP. The water-insoluble NSP can be considered practically undigested by poultry and only soluble NSP has the potential to be digested by birds [3]. However, soluble NSP are known to posses anti-nutritional properties by either

This article is an open access article licensed under the terms of the Creative Commons Attribution License (http://creativecommons. org/licenses/by/2.0) which permits unrestricted use, distribution and reproduction in any medium, provided the work is properly cited. encapsulating nutrients and/or depressing overall nutrient digestibility through gastro-intestinal modifica-tions. Hence, supplementation of non-starch polysaccharide degrading enzymes will enhance the digestibility of the NSP and utilization of these components to the desired level in the chicken.

An attempt was made to assess the effect of pure enzyme combinations on commonly used poultry feed ingredients with the objective of formulating customized enzyme mixtures based on sugar release (The addition of selected carbohydrases will break down NSP, releasing nutrients (energy and protein), as well as reducing the viscosity of the contents) when subjected to two-stage in vitro digestion assay.

\section{Materials and Methods}

The NSP enzymes investigated in present study were cellulase, xylanase, and $\beta$-D-glucanase. These pure enzymes were procured from Advanced BioAgrotech Limited, Pune, India. The activity of cellulase, xylanase, $\beta$-D-glucanase and Protease were 1000000, 1200000, 1600000 and $100000 \mathrm{IU} / \mathrm{g}$, respectively.

The in vitro digestibility studies were undertaken 
for the commonly used feed ingredients for poultry viz., maize, soybean meal, sunflower cake and de-oiled rice bran supplemented with various NSP enzymes oncentrations (xylanase, cellulase and $\beta$ - D-glucanase) and was assessed by two stage in vitro digestion assay of [4] and the total sugars released from two stage in vitro digestion was estimated. The total sugar released from in vitro digestion was assessed as per the procedure described by, [5]. Based on the available literature various enzyme concentrations were selected to formulate different NSP enzymes combinations for commonly used feed ingredients (Table-1).

Table-1. Various enzyme concentrations selected for feed ingredients.

\begin{tabular}{lc}
\hline Enzyme & Concentration (IU/kg substrate) \\
\hline Xylanase & $5000 ; 7500$ and 10000 \\
Cellulase & $50 ; 100$ and 400 \\
$\beta$-D-glucanase & $100 ; 200$ and 400 \\
\hline
\end{tabular}

With three concentrations each of xylanase, cellulase and $\beta$-D-glucanase, twenty seven different combinations were formulated. These enzyme combinations were supplemented to each ingredient and subjected to two stage in vitro NSP digestibility and total sugars released were measured.

Two-stage in vitro digestion assay: About $0.1 \mathrm{~g}$ of ground samples containing different enzyme combinations in triplicate were incubated with $3 \mathrm{ml}$ of $0.1 \mathrm{~N} \mathrm{HCl}$ containing $2000 \mathrm{IU}$ pepsin $/ \mathrm{ml}$ at $40^{\circ} \mathrm{C}$ for 45 minutes to simulate the peptic/gastric phase. To the same tubes after 45 minutes, $1 \mathrm{ml}$ of $1 \mathrm{M} \mathrm{NaHCO}_{3}$ containing $2 \mathrm{mg}$ pancreatin $/ \mathrm{ml}$ were added and incubated for 2 hours at $40^{\circ} \mathrm{C}$ to simulate the pancreatic/intestinal phase. At the end, contents were centrifuged and the supernatant was stored in ice for total sugar estimation.

Total sugar estimation: After pancreatic phase, the total sugars released due to NSP digestion was quantified by phenol-sulphuric acid method as described by [5]. An aliquot of the supernatant $(0.5 \mathrm{ml})$ was diluted to $10 \mathrm{ml}$ with distilled water. To $1 \mathrm{ml}$ of this diluted solution, $1 \mathrm{ml}$ phenol reagent and $5 \mathrm{ml}$ concentrated $\mathrm{H}_{2} \mathrm{SO}_{4}$ was added, and was allowed to stand for 20 minutes at room temperature and the absorbance was read in double beam UV spectrophotometer at 490 $\mathrm{nm}$. The concentration of sugars in the sample was calculated using glucose standard graph. The total sugar released was expressed as $\mathrm{mg} / \mathrm{g}$ substrate/ feed.

Statistical analysis: The data on total sugars released was subjected to statistical analysis using SPSS $16^{\text {th }}$ version and comparison of means was tested using Duncan's multiple range tests [6].

\section{Results}

Maize: The sugars release from maize without enzyme supplementation was $131.2 \mathrm{mg} / \mathrm{g}$. The total sugars release was significantly $(P<0.05)$ higher with supplementation of various enzyme combinations
(Table-2). Significant $(P<0.05)$ interaction was observed for xylanase, cellulase and $\beta$-D-glucanase. At $10000 \mathrm{IU} / \mathrm{kg}$ xylanase concentration, the NSP digestibility was higher at all combinations containing cellulase and $\beta$-D-glucanase (19-27 combinations) compared to control and the sugars release was comparable among all combinations containing 10000 IU/kg xylanase $(170.01-207.66 \mathrm{mg} / \mathrm{g})$. At $7500 \mathrm{IU} / \mathrm{kg}$ xylanase combinations the sugars release was higher in all combinations except in combination containing 400 $\mathrm{IU} / \mathrm{kg} \beta$-D-glucanase. At $5000 \mathrm{IU} / \mathrm{kg}$ xylanase supplementation the NSP digestibility was highest in combination 3 (xylanase-5000, cellulase-50 and $\beta$-Dglucanase-400 IU $/ \mathrm{kg}$ ) followed by combinations 7 and 1 . No effect of enzyme supplementation was observed with combinations $2,4,5$ and 9 in comparison to control.

Soybean meal: No significant interaction was observed for xylanase, cellulase and $\beta$-D-glucanase. Interaction between xylanase and $\beta$-D-glucanase, xylanase and cellulase and cellulase and $\beta$-D-glucanase were also not significant (Table-2). The in vitro sugars release in control was $116.9 \mathrm{mg} / \mathrm{g}$ and increased in various enzyme supplementation groups which, ranged between 162.9 - $191.2 \mathrm{mg} / \mathrm{g}$. The in vitro NSP digestion increased significantly $(P<0.05)$ with xylanase supplementation, irrespective of cellulase and $\beta$-D-glucanase concentrations, but dose of xylanase did not show any difference.

Sunflower cake: The sugars release from sunflower cake with two stage in vitro digestion was $133.20 \mathrm{mg} / \mathrm{g}$ in control and was significantly $(P<0.01)$ increased in enzyme supplemented groups (155.6-175.9 mg/g) irrespective of the combinations (Table 2). Significant $(P<0.01)$ three way interaction was observed among the xylanase, cellulase and $\beta$-D-glucanase enzyme. The two-way interactions between the enzymes were also significant $(P<0.01)$. The highest sugars release was recorded with enzyme combination 20 (xylanase10000 , cellulase-50 and $\beta$-D-glucanase- $200 \mathrm{IU} / \mathrm{kg}$ ) and 10 (xylanase-7500, cellulase-50 and $\beta$-Dglucanase-100 IU/kg), followed by 24 (xylanase10000 cellulase-100 and $\beta$-D-glucanase- $400 \mathrm{IU} / \mathrm{kg}$ ), 19 (xylanase-10000, cellulase-50 and $\beta$-D-glucanase$100 \mathrm{IU} / \mathrm{kg}$ ), 17 (xylanase-7500, cellulase-400, $\beta$-Dglucanase- $200 \mathrm{IU} / \mathrm{kg}$ ), 13 (xylanase-7500, cellulase100 and $\beta$-D-glucanase-100 IU/kg) and 10 (xylanase7500, cellulase-50, $\beta$-D-glucanase-100 IU/ $/ \mathrm{kg}$ )in that order. The sugars release was higher at xylanase concentration of 7500 and $10000 \mathrm{IU} / \mathrm{kg}$, cellulase concentration of 50 and $100 \mathrm{IU} / \mathrm{kg}$ and $\beta$-D-glucanase concentration of $200 \mathrm{IU} / \mathrm{kg}$, irrespective of combinations.

De-oiled rice bran: The release of sugars from de-oiled rice bran during in vitro NSP digestion was 106.64 $\mathrm{mg} / \mathrm{g}$, in control which increased significantly $(P<0.001)$ with enzyme supplementation (147.2187.8) (Table-2). At $5000 \mathrm{IU} / \mathrm{kg}$ xylanase 
Table-2. In vitro NSP digestibility, measured as total sugars released $(\mathrm{mg} / \mathrm{g})$ from feed ingredients supplemented with various NSP enzyme combinations

\begin{tabular}{|c|c|c|c|c|c|c|c|}
\hline \multirow{2}{*}{$\begin{array}{l}\text { Combination No. } \\
\text { Control }\end{array}$} & \multicolumn{3}{|c|}{ Enzyme combination (IU/kg) } & Maize & Soybean meal & Sunflower cake & De-oiled rice bran \\
\hline & 0 & 0 & 0 & $131.2^{f}$ & 116.9 & $133.2^{\mathrm{m}}$ & $106.6^{i}$ \\
\hline 1 & 5000 & 50 & 100 & $197.2^{\mathrm{ab}}$ & 169.6 & $162.3^{\mathrm{ijk}}$ & $179.2^{\mathrm{ab}}$ \\
\hline 2 & 5000 & 50 & 200 & $161.4^{\text {bcdef }}$ & 172.4 & $168.3^{\text {cdefg }}$ & $174.33^{\text {bcde }}$ \\
\hline 3 & 5000 & 50 & 400 & $207.4^{\mathrm{a}}$ & 164.0 & $162.2^{1 \mathrm{jk}}$ & $175.5^{\text {bcde }}$ \\
\hline 4 & 5000 & 100 & 100 & $142.8^{\text {ef }}$ & 171.2 & $155.6^{\prime}$ & $174.5^{\text {bcde }}$ \\
\hline 5 & 5000 & 100 & 200 & $150.9^{\text {cdef }}$ & 178.1 & $169.8^{\text {bcdef }}$ & $163.9^{\text {efg }}$ \\
\hline 6 & 5000 & 100 & 400 & $187.2^{\mathrm{abcd}}$ & 177.4 & $162.0^{\mathrm{jk}}$ & $177.3^{\mathrm{abcd}}$ \\
\hline 7 & 5000 & 400 & 100 & $197.3^{\mathrm{ab}}$ & 190.5 & $164.5^{\text {ghijk }}$ & $159.8^{\mathrm{g}}$ \\
\hline 8 & 5000 & 400 & 200 & $178.1^{\text {abcde }}$ & 178.1 & $168.1^{\text {defgh }}$ & $173.7^{\text {bcdef }}$ \\
\hline 9 & 5000 & 400 & 400 & $162.1^{\text {bcdef }}$ & 171.2 & $165.3^{\text {fghijk }}$ & $173.9^{\text {bcdef }}$ \\
\hline 10 & 7500 & 50 & 100 & $179.7^{\text {abcde }}$ & 171.1 & $171.1^{\text {abcde }}$ & $169.0^{\text {bcdefg }}$ \\
\hline 11 & 7500 & 50 & 200 & $182.9^{\mathrm{abcd}}$ & 163.4 & $175.1^{\mathrm{a}}$ & $166.5^{\text {cdefg }}$ \\
\hline 12 & 7500 & 50 & 400 & $161.1^{\text {bcdef }}$ & 186.8 & $165.5^{\text {fghijk }}$ & $171.7^{\text {bcdefg }}$ \\
\hline 13 & 7500 & 100 & 100 & $181.0^{\mathrm{abcd}}$ & 184.4 & $171.1^{\text {abcde }}$ & $187.8^{\mathrm{a}}$ \\
\hline 14 & 7500 & 100 & 200 & $164.1^{\text {bcdef }}$ & 191.2 & $173.0^{\mathrm{abc}}$ & $173.0^{\text {bcdef }}$ \\
\hline 15 & 7500 & 100 & 400 & $150.5^{\text {cdef }}$ & 179.6 & $165.6^{\text {fghijk }}$ & $179.4^{\mathrm{ab}}$ \\
\hline 16 & 7500 & 400 & 100 & $171.8^{\mathrm{abcde}}$ & 183.4 & $167.2^{\text {efghi }}$ & $167.0^{\text {bcdefg }}$ \\
\hline 17 & 7500 & 400 & 200 & $178.6^{\text {abcde }}$ & 177.5 & $171.2^{\text {abcde }}$ & $164.9^{\text {defg }}$ \\
\hline 18 & 7500 & 400 & 400 & $149.4^{\text {def }}$ & 179.7 & $163.2^{\mathrm{hijk}}$ & $173.0^{\text {bcdef }}$ \\
\hline 19 & 10000 & 50 & 100 & $207.7^{\mathrm{a}}$ & 163.8 & $172.1^{\text {abcd }}$ & $164.8^{\text {defg }}$ \\
\hline 20 & 10000 & 50 & 200 & $175.6^{\text {abcde }}$ & 179.0 & $175.9^{\mathrm{a}}$ & $166.1^{\text {bcdefg }}$ \\
\hline 21 & 10000 & 50 & 400 & $184.5^{\mathrm{abcd}}$ & 174.3 & $163.3^{\text {hijk }}$ & $169.1^{\text {bcdefg }}$ \\
\hline 22 & 10000 & 100 & 100 & $188.3^{\mathrm{abc}}$ & 163.0 & $166.1^{\text {fghijk }}$ & $164.0^{\mathrm{efg}}$ \\
\hline 23 & 10000 & 100 & 200 & $185.7^{\text {abcd }}$ & 166.7 & $166.6^{\text {efghij }}$ & $178.1^{\mathrm{abc}}$ \\
\hline 24 & 10000 & 100 & 400 & $176.4^{\text {abcde }}$ & 177.0 & $173.8^{\mathrm{ab}}$ & $147.2^{\mathrm{h}}$ \\
\hline 25 & 10000 & 400 & 100 & $172.1^{\mathrm{abcde}}$ & 169.0 & $161.2^{k}$ & $161.6^{\mathrm{fg}}$ \\
\hline 26 & 10000 & 400 & 200 & $170.0^{\text {abcde }}$ & 165.9 & $163.7^{\text {ghijk }}$ & $173.6^{\text {bcdef }}$ \\
\hline 27 & 10000 & 400 & 400 & $186.5^{\mathrm{abcd}}$ & 164.1 & $164.2^{\text {ghijk }}$ & $159.7^{g}$ \\
\hline \multirow[t]{4}{*}{ Xylanase } & 0 & --- & --- & 131.2 & $116.9^{b}$ & 133.2 & 106.6 \\
\hline & 5000 & --- & --- & 176.1 & $174.7^{\mathrm{a}}$ & 164.2 & 172.5 \\
\hline & 7500 & --- & --- & 168.8 & $179.67^{\mathrm{a}}$ & 169.2 & 172.5 \\
\hline & 10000 & --- & --- & 183.0 & $169.2^{\mathrm{a}}$ & 167.4 & 164.9 \\
\hline \multirow[t]{4}{*}{ Cellulase } & -- & 0 & --- & 131.2 & 116.9 & 133.2 & 106.6 \\
\hline & --- & 50 & --- & 184.2 & 171.6 & 168.4 & 170.7 \\
\hline & --- & 100 & --- & 169.7 & 176.5 & 167.1 & 171.7 \\
\hline & --- & 400 & --- & 174.0 & 175.5 & 165.4 & 167.5 \\
\hline \multirow[t]{4}{*}{$\beta$-D glucanase } & --- & -- & 0 & 131.2 & 116.9 & 133.2 & 106.6 \\
\hline & --- & --- & 100 & 182.0 & 174.0 & 165.7 & 169.7 \\
\hline & --- & --- & 200 & 171.9 & 174.7 & 170.2 & 170.5 \\
\hline & --- & --- & 400 & 173.9 & 174.9 & 165.0 & 169.6 \\
\hline SEM & & & & 2.87 & 2.11 & 2.87 & 1.96 \\
\hline \multicolumn{8}{|l|}{$\mathbf{P}$ value } \\
\hline \multicolumn{4}{|l|}{ Xylanase } & 0.034 & 0.037 & 0.001 & 0.001 \\
\hline \multicolumn{4}{|l|}{ Cellulase } & 0.025 & 0.418 & 0.001 & 0.051 \\
\hline \multicolumn{4}{|l|}{$\beta-D$ glucanase } & 0.136 & 0.971 & 0.001 & 0.875 \\
\hline \multicolumn{4}{|c|}{ Xylanase $\mathrm{x}$ Cellulase } & 0.263 & 0.333 & 0.001 & 0.003 \\
\hline \multicolumn{4}{|c|}{ Xylanase $x \beta-D$ glucanase } & 0.027 & 0.640 & 0.001 & 0.001 \\
\hline \multicolumn{4}{|c|}{ Cellulase $\times$ $\beta-D$ glucanase } & 0.357 & 0.421 & 0.001 & 0.015 \\
\hline \multicolumn{4}{|c|}{ Xylanase $\times$ Cellulase $\times \beta-D$ glucanase } & 0.038 & 0.612 & 0.001 & 0.006 \\
\hline
\end{tabular}

Each value is the average of triplicate analysis, Means with different superscripts in a column differ significantly $(P<0.05)$

concentration, the various combinations with cellulase and $\beta$-D-glucanase were comparable, except lower values in combination 5 (xylanase-5000, cellulase- 100 and $\beta$-D-glucanse-200 IU/kg) and 7 (xylanase-5000, cellulase-400 and $\beta$-D-glucanase-100 IU $/ \mathrm{kg}$ ). At $10000 \mathrm{IU} / \mathrm{kg}$ xylanase concentration, the highest sugar release was observed at combination 13 (xylanase7500 , cellulase-100 and $\beta$-D-glucanase-100 IU/ $/ \mathrm{kg}$ ), while other combinations were comparable. Of all the 27 combinations the highest sugar release was observed in combination 13 (xylanase-7500, cellulase100 and $\beta$-D-glucanase-100 IU/kg) and the lowest sugar release was observed in combination 24 (xylanase-10000, cellulase-100, $\beta$-D-glucanase-400 $\mathrm{IU} / \mathrm{kg})$.

\section{Discussion}

Maize: The NSP content of maize as reported by various workers varied from 8.10 to $10.30 \%$ [7-11]. While, in barley the NSP content was higher (16.7 and $18.8 \%)[7,8,12]$. In wheat NSP content varied from $11.4-12.8 \%[7,8,12]$ and in rye varied from 13.2-16.10 $\%[8,13,14]$. On the other hand, NSP content of maize was comparable to sorghum (5.6-11.0\%) [7,8,9,12], and finger millet [9].

The total sugars released from maize with two stage in vitro digestibility assay without enzyme supplementation was $131.20 \mathrm{mg} / \mathrm{g}$ (Table-2). The NSP enzymes used viz., xylanase $(5000,7500,10000 \mathrm{IU} / \mathrm{kg}$ substrate), cellulase $(50,100,400 \mathrm{IU} / \mathrm{kg}$ substrate), $\beta$ D-glucanase $(100,200,400 \mathrm{IU} / \mathrm{kg}$ substrate) increased 
$(\mathrm{P}<0.05)$ the total sugars release from the maize (142.81 to $207.7 \mathrm{mg} / \mathrm{g}$ ), except for combination 2 (xylanase 5000, cellulase 50, $\beta$-D-glucanase 200), 4 (xylanase 5000, cellulase 100, $\beta$-D-glucanase 100), 5 (xylanase 5000, cellulase 100, $\beta$-D-glucanase 200) and 9 (xylanase 5000, cellulase 400, $\beta$-D-glucanase 400). The sugars release was highest in enzyme combination 3 (xylanase 5000 , cellulase $50, \beta$-D-glucanase 400 ) $(207.4 \mathrm{mg} / \mathrm{g})$ and 19 (xylanase 10000 , cellulase $50, \beta$ D-glucanase 100) $(207.7 \mathrm{mg} / \mathrm{g})$.

Similarly [10] reported higher sugars release from maize supplemented with various enzyme combinations with cellulase, xylanase and pectinase. The highest sugars release $(315 \mathrm{mg} / \mathrm{g})$ was observed with enzyme combination (cellulase 408, xylanase 2081 and pectinase $369 \mathrm{U} / \mathrm{g}$ enzyme) and (cellulase 405, xylanase 2066 and pectinase $369 \mathrm{U} / \mathrm{g}$ enzyme).

In vitro studies conducted by [15] revealed higher dose requirement of xylanase (60000 and 240000 $\mathrm{IU} / \mathrm{kg}$ substrate) along with pectinase and glucanase for barley and rye. The enzyme dose used was higher than that used for maize, used in the present study and as reported by [10] which might be due to higher NSP content in barley and rye compared to maize. Similarly in-vitro studies with multiple enzyme addition (high, medium and low) to extruded and non- extruded corn based diets for pigs improved nutritional value in terms of coefficient of apparent digestibility (CAD), starch and NDF [16]. Further [17] also reported that reconstitution of maize with added enzymes improved pepsin pancreatic digestibility (IVPPD) 20\% over control.

Soybean meal (SBM): The NSP content of soybean meal as reported by previous workers ranged from 17.1 to $30.3 \%$ [7-10,14]. However [11] reported low Nonstarch Polysaccharides content in terms of NDF (11$64 \%$ ), and ADF (7.25\%). About $30 \%$ of NSP in SBM was galactose with glucose, uronic acids, arabinose and xylose [18]. Higher in vitro sugars release was reported with use of xylanase $(1080 \mathrm{IU} / \mathrm{kg})$, cellulase $(10.8 \mathrm{IU} / \mathrm{kg})$ and pectinase $(10800 \mathrm{IU} / \mathrm{kg})$ combination for soy bean meal $(4.56 \mathrm{mg} / \mathrm{ml})$ compared to control $(3.39 \mathrm{mg} / \mathrm{ml})[9]$.

The in vitro sugars release from soybean meal in the present study was $116.9 \mathrm{mg} / \mathrm{g}$ and ranged between $163.43-190.5 \mathrm{mg} / \mathrm{g}$, when supplemented with various enzyme combinations (1-27) (Table-2). No significant $(P<0.05)$ effect was observed between control and enzyme supplementation for soybean meal (Table-2). Though insignificant (39.35-63.55\%) higher sugars release was observed with supplementation of xylanase (5000 to $10000 \mathrm{IU} / \mathrm{kg}$ substrate), irrespective of cellulase and $\beta$-D-glucanase. The dose rate of 5000 $\mathrm{IU} / \mathrm{kg}$ was sufficient for soybean meal. The sugars release from soybean meal was in agreement with the sugars release extrapolated from the studies of [18].

The in vitro sugars release from soybean meal in studies of [10] was $(360 \mathrm{mg} / \mathrm{g})$ and the sugars release increased with supplementation of enzyme combination (cellulase 408, xylanase 2081 and pectinase $369 \mathrm{U} / \mathrm{g}$ of enzyme) and (cellulase 405, xylanase 2066 and pectinase $369 \mathrm{U} / \mathrm{g}$ of enzyme) followed by (cellulase 468 , xylanase 2143 and pectinase $360 \mathrm{u} / \mathrm{g}$ of enzyme) and (cellulase 353, xylanase 1975 and pectinase 353 $\mathrm{U} / \mathrm{g}$ of enzyme).

Sunflower cake: The NSP content of sunflower cake ranged from 21.0 to $55.2 \%$ [7-10,19,20]. The NSP content of sunflower cake was higher than rapeseed meal $(18.8-32 \%)$ as reported by various workers $[7,8,21,22]$.

Higher sugars release for enzyme combination was reported by [10]; (cellulase 408, xylanase 2081 and pectinase $369 \mathrm{U} / \mathrm{g}$ of enzyme) and (cellulase 405, xylanase 2066 and pectinase $369 \mathrm{U} / \mathrm{g}$ of enzyme) than (cellulase 468, xylanase 2143 and pectinase $360 \mathrm{U} / \mathrm{g}$ of enzyme), (cellulase 353, xylanase 1975 and pectinase $353 \mathrm{U} / \mathrm{g}$ of enzyme) and control. [9] reported that xylanase and cellulase combination was superior for sunflower meal than xylanase, cellulase and pectinase combination.

The sugars release from sunflower cake without any enzyme supplementation in the present study was $133.2 \mathrm{mg} / \mathrm{g}$ and was lower than the value reported by [10] (Table-2). NSP enzyme supplementation to sunflower cake resulted in increased $(P<0.01)$ total sugars release compared to non supplemented group. The NSP enzymes supplemented to sunflower cake at various doses and combination, the in vitro sugars release was significantly $(P<0.01)$ higher than control. Among various enzyme combinations comprising of xylanase, cellulase and $\beta$-D-glucanase tested, the xylanase combination consisting of (7500 or 10000 $\mathrm{IU} / \mathrm{kg}$ ), cellulase (50 IU/ $\mathrm{kg}$ ) and $\beta$-D-glucanase $(200$ IU/kg) recorded higher total sugars release (175.94 $\mathrm{mg} / \mathrm{g}$ ). The 27 combinations tested have shown considerable increase in total sugars released and ranged between 161.18 and $175.94 \mathrm{mg} / \mathrm{g}$. The sugars release was higher at xylanase combination of 7500 and $10000 \mathrm{IU} / \mathrm{kg}$. While for cellulase 50 and $100 \mathrm{IU} / \mathrm{kg}$ had comparatively higher sugars release than $400 \mathrm{IU}$ and $\beta$-D-glucanase $200 \mathrm{IU}$ was having highest sugars release.

Similarly [23] reported significant increase in the release of glucose, other reducing sugars and in organic phosphorous due to addition of enzyme mixtures to sunflower meal. [10] also reported improved sugars release in enzyme supplemented group. The influence of cellulase was clearly seen in the present study and was in accordance with the findings of the $[9,10]$.

De-oiled rice bran (DORB): The in vitro sugars release from de-oiled rice bran (DORB) without enzyme supplementation was $106.6 \mathrm{mg} / \mathrm{g}$ and was much lower than the sugars release of the other ingredients (maize, soybean meal and sunflower cake) tested (116.9 to $133.2 \mathrm{mg} / \mathrm{g}$ ). This might be due to higher NSP content in the DORB than other ingredients. The NSP content of DORB as reported by $[9,11,24]$ was $53.54,59.97$ and $65.3 \%$, respectively. 
The in vitro digestibility of DORB with various enzyme combinations significantly improved sugars release $(147.19$ to $187.80 \mathrm{mg} / \mathrm{g})$ than no enzyme supplementation $(106.64 \mathrm{mg} / \mathrm{g})$. The enzyme combination of xylanase $(7500 \mathrm{IU} / \mathrm{kg})$, cellulase $(100 \mathrm{IU} / \mathrm{kg})$, $\beta$-D-glucanase $(100 \mathrm{IU} / \mathrm{kg})$ yielded highest sugars release $(187.80 \mathrm{mg} / \mathrm{g})$ than other combinations tested and varied between 147.19 to $187.80 \mathrm{mg} / \mathrm{g}$ (Table-2).

The sugars release from DORB was highest $(P<0.01)$ for 5000 and $7500 \mathrm{IU} / \mathrm{kg}$ concentration of xylanase compared to $10000 \mathrm{IU} / \mathrm{kg}$ and a trend of higher $(P<0.01)$ sugars release was observed for $50 \mathrm{IU}$ and $100 \mathrm{IU} / \mathrm{kg}$ compared to $400 \mathrm{IU} / \mathrm{kg}$ cellulase. No effect of $\beta$-D-glucanase was observed in tested range (100-400 IU/kg). Similarly, [9] reported that xylanase $(1080 \mathrm{IU} / \mathrm{kg})$, cellulase $(10.8 \mathrm{IU} / \mathrm{kg})$ and pectinase $(10800 \mathrm{IU} / \mathrm{kg})$ combination was superior to the other enzyme combinations having $\beta$-D-glucanase. In-vitro study conducted by [25] showed increased total sugar release of $36.97 \%$ to $53.64 \%$ from cocoa pod husk with addition of commercial extra cellular exogenous fibro lytic enzymes.

\section{Conclusion}

It is concluded that ' $n$ ' number of NSP enzyme combinations can be screened for their efficiency to digest NSPs present in various feed ingredients commonly used in poultry rations by employing twostage in vitro digestibility assay as a tool.

\section{Authors' contribution}

$\mathrm{JN}$ and $\mathrm{DN}$ designed the experiment, implemented the design, analyzed data and prepared the manuscript; YRR and STVR revised the manuscript. All authors read and approved the final manuscript.

\section{Acknowledgements}

The Authors are thankful to authorities of Sri Venkateswara Veterinary University for providing fund and infrastructure for this study.

\section{Competing interests}

The authors declare that they have no competing interest.

\section{References}

1. Rodica, Capriţa., Adrian, Capriţa. and Calin, Julean. (2010) Biochemical Aspects of Non-Starch Polysaccharides. Animal Science and Biotechnologies 43 (1) 368-375.

2. Carre, B. (1993) European Symposium Poultry Nutrition, WPSA, 5-9 September, Jelena Poland, pp. 148-1 63.

3. Bedford, M. R. and Classen, H. L. (1993) An in vitro assay for prediction of broiler intestinal viscosity and growth when fed rye-based diets in the presence of exogenous enzymes. Poultry Science. 72 : 137-143.

4. Dubois, M., Gilles, K. A., Hamilton, J. K., Rebers P. A. and Smith F. (1956) Colorimetric method for determination of sugars and related substances. Analytical Chemistry. 28 : 350-356.

5. Duncan, D. D. (1955) Multiple range and multiple ' F' test. Biometrics. 11:1-42.

6. Carre, B. and Brillouet, J. M. (1986) Yield and cell wall residues isolated from various feed stuffs used for nonruminant farm animals. Journal of Science Food Agriculture.
37: 341-351.

7. Classen, H. L. (1996) Enzymes in action. Feed Mix. 4 (2): 22-28.

8. Malathi, V. and Devegowda, G. (2001) In vitro evaluation of non starch polysaccharide digestibility of feed ingredients by enzymes. Poultry Science. 80: 302-305.

9. Chandra, Reddy (2003) Influence of enzyme supplementation on son-starch polysaccharide content in feed ingredients. M.V.Sc. Thesis ANGR Agricultural University, Hyderabad.

10. Bharathidasan, A., Chandrasekaran, D., Natarajan, A., Ravi, R., Viswanathan, K. and Ezhilvalavan, S. (2008) Non-starch polysaccharides and phytate phosphorus content of commonly available poultry feed ingredients. Tamilnadu Journal of Veterinary Animal Sciences 5: (1) 20-24.

11. Nyman, M. M., Siljestrom, B., Pedersen, K. E., Batchknudsen, N. E., Asp, C. G., Johansson, E. O. (1984). Dietary fibre content composition in six cereals at different extraction rates. Cereal Chemistry. 61 (1): 14-19.

12. Englyst, H. (1989) Classification measurement of plant polysaccharides. Animal Feed Science and Technology 23 : 27-42.

13. Smits, C. H. M. and Annison, G. (1996) Non starch plant polysaccharides in broiler nutrition towards a physiologically valid approach to their determination. World Poultry Science Journal. 5: 203-221.

14. Castonan, J. I. R., Flores, M. P. and Petterson D. (1997) Mode of degradation of non-starch polysaccharides by feed enzyme preparations. Animal Feed Science and Technolog. 68:361-365.

15. Li, Yong., Fang, Zhengfeng., Dai, Jinjun., Partridge, Gary., $\mathrm{Ru}$, Yingjun and Peng, Jian (2010) Corn extrusion and enzyme addition improves digestibility of corn/soy based diet by pigs: In vitro and in vivo studies. Animal Feed Science and Technology 158(34):146-154.16.

16. Manvar, S. J. and Mandal, A. B. (2008) Availability of certain nutrients in cereals reconstituted with or without enzymes for chickens. Journal of the Science of Food and Agriculture 88: (4) 699-706.

17. Meng, X. and Slominski, B. A. (2005) Nutritive values of corn, soybean meal, canola meal, and peas for broiler chickens as affected by a multicarbohydrase preparation of cell wall degrading enzymes. Poultry Science. 84: 12421251.

18. Dusterhoft, E. M. and Voragen A. G. J. (1991) Non starch polysaccharides from sunflower (Helianthus annus) meal and palm kernel (Elaeis guineenis) meal preparation of cell wall material and extraction of polysaccharide fractions. Journal of Science Food and Agriculture 55: 411-422.

19. Bharathidasan, A., Chandrasekaran, D., Natarajan, A., Viswanathan, K. and Ezhilvalavan, S. (2009) In vitro enzyme assay of commercial feed enzymes. Tamilnadu Journal of Veterinary Animal Sciences 5: (1) 20-24.

20. Slominski, B. A. and Campbell, L. D. (1990) Non-starch polysaccharides of canola meal: Quantification, digestibility in poultry and potential benefit of dietary enzyme supplementation. Journal of Science Food and Agriculture 53: 175184.

21. Siddiqui, I. R. and Wood, P. (1997) Carbohydrates of rapeseed: A review. Journal of Science Food and Agriculture 28:530-538.

22. Ramesh, J. and Chandrasekaran, D. (2012) In vitro evaluation of feed grade enzymes. Indian Veterinary Journal. 89 (4) : 76-78.

23. Annison, G., Moughan, P. J. and Thomas, D. V. (1995) Nutritive activity of soluble rice bran arabinoxylans in broiler diets. British Poultry Science 36: 479-488.

24. Francis, Alemawor., Dzogbefia, V. P., Emmanuel, O. K. Oddoye., Oldham, J. H. (2009) Enzyme cocktail for enhancing poultry utilization of cocoa pod husk. Scientific Research and Essay 4 (6) pp. 555-559.

$* * * * * * * *$ 